\title{
The Right to Rehabilitation with Regards to the International Human Rights Law
}

Sevinc I*

Istanbul Bilgi Üniversitesi, Turkey

*Corresponding author: Sevinc I, Istanbul Bilgi Üniversitesi, Turkey, E-mail: inan.sevinc@bilgi.edu.tr

Citation: Sevinc I (2019) The Right to Rehabilitation with Regards to the International Human Rights Law. J Case Rep Stud 7(2): 202. doi: 10.15744/2348-9820.7.202

Received Date: September 03, 2018 Accepted Date: April 24, 2019 Published Date: April 26, 2019

\begin{abstract}
Rehabilitation is a preferable form of reparation mechanisms when there is a violation resulting from acts of torture, cruel, inhuman or degrading treatment. The reason is that rehabilitation, as in individual measure, might play an essential role in order to reduce and diminish the consequences of such violations as much as possible. Despite its importance, international law has maintained silence on rehabilitation as an element of reparation for too long and this gap has been filled, on normative ground, by international human rights law conventions and by the jurisprudence of international human rights law mechanisms of the United Nations and Inter-American Court of Human Rights Law.
\end{abstract}

Keywords: Effective Investigation; European Court of Human Rights; International Human Rights Law; Impunity; Right to Truth

\section{Introduction}

Rehabilitation ("Rehabilitation") is a preferable form of reparation mechanisms when there is a violation resulting from acts of torture, cruel, inhuman or degrading treatment. The reason is that rehabilitation, as in individual measure, might play an essential role in order to reduce and diminish the consequences of such violations as much as possible [1]. Also, it is clear for some that the research for reparation has a therapeutic benefit with other medical or psychological treatments for the victims [2]. And taking into consideration the fact that the rehabilitation is the total of the process during when the victim deploys in order to reach the elimination of the consequences of the act of violation, the research there is also an important part [3].

The rehabilitation, without having a unique significance, is defined in accordance with the importance given to the aspects which we have aforementioned. According to the fundamental principles and guidelines concerning the law in this field and for the victims of flagrant violations of international human rights and for the grave international human rights violations, the "rehabilitation should include medical and psychological care as well as legal and social services" [4]. According to the International Rehabilitation Council for Torture Victims, rehabilitation in fact "is a process that recognises the victims' agency and empowerment and takes into account their individual needs as well as the cultural, social and political background and environment in which they live" [5]. For Dinah Shelton, rehabilitation is "a process which sees to reestablish the health and reputation of the victim after the trauma is caused by an gross violation to the victim's physical or mental integrity. [...] It has the aim to reestablish what has been lost. The rehabilitation searches to reach the maximum physical and psychological aptitude addressed to a person, to the family, to the local community and the society as well [6]. In a broader sense, the rehabilitation does not only include an individual treatment but is also a recovery procedure for the society and at the end, reintegration for all the public life [7].

Whatever definition is attributed to the rehabilitation, they could all be categorised in two approaches. The first one, holistic approach, departs from the idea that the necessities of the victims could not be satisfied without a vaste and multidisciplinary context which encompasses medical and psychological treatment, psychosocial support, the judicial services and social reintegration [8]. This approach requires the States to establish a rehabilitation system integrating at least physical and psychological services, as well as social, judicial and financial services, which needs to be placed at the disposition of all persons who are in need, and of course, under proper circumstances in each case. The second approach is the narrow concept which considers the rehabilitation exclusively in terms of physical and psychological treatment.

\section{Consideration by the International Law}

International law has stayed silence on rehabilitation as an element of the reparation for a long time. International law's integration of rehabilitation as a particular form of reparation is recent [9]. In fact, The Convention against Torture and Other Cruel, Inhuman 
or Degrading Treatment or Punishment (1984) is the first instrument which includes rehabilitation as a form of compensation in its Article $14 \$ 1$. This article states that "Each State Party shall ensure in its legal system that the victim of an act of torture obtains redress and has an enforceable right to fair and adequate compensation, including the means for as full rehabilitation as possible. In the event of the death of the victim as a result of an act of torture, his dependants shall be entitled to compensation." The integration of rehabilitation as an aim to reach has followed by other conventions and textes of international law which made reference to it. Rehabilitation has especially been given an important place among other forms of reparation on the final version of "Basic principles and guidelines on the right to a remedy and reparation for victims of gross violations of international human rights law and serious violations of human rights law" [10]. Organs of United Nations related to the international law has made them in line with the normative evolutions of the international law. For example, the United Nations Human Rights Committee ("Human Rights Committee") clearly recognised the rehabilitation as a form of reparation among others [11]. the United Nations Committee Against Torture recommends each State to assure a medical, psychological and social rehabilitation [12]. To the victims of torture or to assure an adequate compensation including damages, rehabilitation and medical and psychological treatment to the victims of torture in a general manner [13].

Moreover, the Committee on the Elimination of All Forms of Discrimination Against Women recommends all States to take "measures to create or support services for victims" which contains special medical personnel formed and reinsertion services [14].

\section{Controversial Approach of Regional Jurisdictions}

On regional level, none of the related conventions on human rights law include rehabilitation as a form of reparation in their founding texts. Moreover, this analysis might be put into perspective when we take a look at the jurisprudence of the regional jurisdictions, especially of the Inter-American Court, which fills this normative gap and plays a pioneer role in this matter.

\section{The Position Held by the Inter-American Court of Human Rights}

Inter-American Court recognises that rehabilitation falls into the category of other forms of reparations along with the obligation to investigate, satisfaction measures, guarantees of non-repetition ("Guarantees of Non-Repetition") and that other adequate reparations require, among others, also rehabilitation measures [15-17]. In its decision Velasquez Rodriquez v. Honduras, the Court started to take the health dimension of the rehabilitation into consideration while determining the total sum to grant as compensation [18]. Other elements of rehabilitation might also be, where appropriate, the costs of the medical treatment of the family for the relatives of the victims as well as future medical costs $[19,20]$. The Court shows great sensibility in the cases with gross human rights law violations (arbitrary execution, torture or disparition). The Court might also grant it automatically, in the cases where neither the Commission, nor the family has filed for the compensation of future medical costs [21]. This is according to the gravity of the effects of the violation caused by the circumstances of the case. According to the Court's decision 19 Merchants v. Colombia, the Court has evaluated her jurisprudence considerably in the matter of rehabilitation in kind and prescribed it under another form of reparation and also granted medical treatment to the family of the victim [22]. This approach is followed by the attribution of another element of the rehabilitation in kind which the Court has granted medical and psychological care, assistance programmes for education and professional training [23].

Although the jurisprudence of the Inter-American Court has been criticised for being insufficient and incoherent on the grounds that often in some cases the Court grants uniquely psychological treatment without taking into consideration of rehabilitation or in pecuniary form, if we compare her stance with the stance of European Court of Justice, it is not hard to state that the European Court has shown much less ambition and has been more timid in comparison to the Inter-American court and its jurisprudence $[24]$.

\section{European Court of Human Rights' Approach}

In comparison with the position held by international law from normative and judicial aspects as well as the regional organs of the human rights law in relation to the question of the rehabilitation, we might examine the jurisprudence of the European Court of Human Rights (hereinafter: ECHR or the Court) since the Court does not recognise rehabilitation as a form of reparation. The developments has not been taken into consideration by the Court despite the importance of this form for the victims of the violations under Article 3. Bearing in mind the absence of specific measures concerning the rehabilitation of victims and/or any such measure adopted by the ECHR as individual measures and in the absence of creating rehabilitation centers as general measures, it seems important to study the jurisprudence of the Court to see whether the Court grants any compensation that permits psychological treatment with the objective of rehabilitation. We might note that the Court grants, on a case by case approach, equitable satisfaction ["Equitable Satisfaction"] in three categories, namely material damage, moral damage and costs. In the absence of a practice by the Court regarding rehabilitation, it is appropriate to look at the general politics of the Court related to the equitable satisfaction, particularly on the related aspects of the moral and material damages since it could be conceived as returning to achieve the objective of rehabilitation. A specific compensation on rehabilitation is not examined separately apart from the sum corresponding to the moral and material damages and this part of the damages is absorbed in the moral part from 
a psychological or material aspect and from a medical treatment aspect of rehabilitation or the damage is confused with the equitable satisfaction $[25,26]$.

Within the scope of material damages, contrary to a lot of decisions that have been given as grave violation (arbitrary execution, torture or disappearance), in three cases, the Court has dealt with the question of medical costs due to the violation and the Court has examined in a strict manner in the first place by verifying whether there is a link between the violation assessed and in the second place the documents which serve as proof. Both for the medical costs incurred and to-be incurred, the Court has applied a strict proceeding for the demands and required tangible proof for these. The examination of the compensation granted by the Court to the requests under the title of material damages by the victimes concerning the past or future legal costs accepted as medical costs demonstrate that the Court continue to apply in her formalist approach in this subject. In other terms, the Court demands tangible proof for the costs. Taking into consideration that the objective consequences vary from one case to another, a compensation needs to be granted in the absence of proof as well.

As for the psychological dimension of the rehabilitation, it was certainly included in the compensation for moral damages. It needs to be accepted that the calculation of the compensation to be granted under the moral damages, although it has its own difficulties given that a purely personal nature of moral damages and as there is no objective measurement tool available for the victim. These damages are determined in a subjective manner and varies from one case to another according to the particular circumstances. This subjective aspect permits us, among others, to evaluate the importance of compensation granted by the Court to the degree of violation [27].

\section{Conclusion}

The position held by the ECHR in the recent decisions must be welcomed and this position needs continue, especially in the cases of grave violations. Many of the reforms do much to ameliorate living standards of the victims of these violations so they can enjoy equitable satisfaction in accordance with the consequences to which they are subjected. In order to do this, although the Court has granted automatic satisfaction as an exception before, this needs to be spread to the violations of Article 3 in principle as a substantial part, ceasing to make use of the developing legislation concerning the granting of damages. The reason is that, as it happens often and as aforementioned, the Court refuses to grant damages in some cases or find a substantial violation of Article 3 on the grounds of absence of demand or lacks the submission of the demand in the given time. Also, the Court needs to equally grant fair damages to the victims of this kind of violations regardless the existence of proof or submission of demand of equitable satisfaction on the bases of the assumption that the consequences of such violation would generate the necessity of at least a medical, physical or psychological treatment. Other than that, it needs to be underlined that not granting damages, as well as the absence of an indication of rehabilitation as a measure would make the effects that were born even worse. In this field, it is necessary from the Court's part to determine a basic amount to grant the victims which would serve as medical costs in the past or future. This point of view might help mobiliser the States as well so that they build readaptation centers which are open, among others, automatically to the victims who win the case before the Court. If this is realised and depending on the effectiveness of the centers, the Court might always put an end to the application of such a basic amount until the Court leaves her classical position of non-granting rehabilitation as a measure to a victim. Also, it could be suggested for the Court to evaluate the costs of the rehabilitation programmes and grant it to the victims or to ask the State to provide rehabilitation. At least the Court might take the European Convention on Compensation of Victims of Violent Crimes as a guide during the evaluation of the amount to grant under the title of satisfaction, especially Article 4, which is important for the person who would take the rehabilitation. With its own terms, "Compensation shall cover, at least, loss of earnings, medical and hospitalisation expenses and funeral expenses and, as regards dependants, loss of maintenance."

\section{Decisions}

\section{European Court of Human Rights}

Batı and others v. Turkey, ref. 33097/96 and 57834/00, decision of 3 June 2004.

Chember v. Russia, ref. 7188/03, decision of 3 July 2008, $\$ 77$.

Mengesha Kimfe v. Switzerland, ref. 24404/05, decision of 29 July 2010, $\$ 76$

N.F. v. Italy, ref.37119/97, decision of 2 August 2001.

Türkmen v. Turkey, ref. 43124/98, decision of 19 December 2006.

\section{Inter-American Court of Human Rights}

19 merchants v. Colombia, decision of 5 July 2004.

Blake v. Guatemala, decision of 22 January 1999, judgement on reparations and costs.

Bulacio v. Argentina, decision of 18 September 2003 judgement on merits, reparations and costs.

Castillo Paez v. Peru, decision of 27 November 1998 judgement on reparations and costs.

Gutiérrez Soler v. Colombia, decision of 12 September 2005 judgement on merits, reparations and costs. 
Juvenile Re-education Institute v. Paraguay, decision of 2 September 2004 judgement on preliminary objections, merits, reparations and costs.

Tiu Tojin v. Guatemala, decision of 26 November 2008, judgement on merits, reparations and costs.

Valle Jaramillo v. Colombia, decision of 27 novembre 2008, judgement on merits, reparations and costs.

Velasquez Rodriguez v. Honduras, decision of 21 July 1989 judgement on reparations and costs.

\section{United Nations Human Rights Committee}

George Kazantzis v. Cyprus, Comm. n972/2001, Opinion of 7 August 2003.

Bernadette Faure v. Australia, Comm. n¹036/2001, Opinion of 31 October 2005.

\section{References}

1. Giffard C (2000) The torture reporting handbook, How to document and respond to allegations of torture within the international. Human rights centre, University of Essex, Part III, 7.1.

2. Dalton P (2002) Some perspectives on torture victims, reparation and mental recovery. 1: 32-9.

3. Carmichael K, McKay F, Dishington B (1996) The need for REDRESS: why seek a remedy? Reparation as rehabilitation. Torture 6: 7-9.

4. General Assembly Resolution 60/147 (2008) United Nations Audiovisual Lib Int Law 1-5.

5. Rehabilitation of torture victims.

6. Shelton D (2005) Remedies in international Human rights law (2nd Edn). Oxford Univ Press, New York, USA.

7. Johnson DA, Miles SH (2009) As full rehabilitation as possible: torture survivors and right to care. Swiss Human Rights Book, Switzerland 3: 222.

8. Echeverria G (2006) Redressing torture: a genealogy of remedies and enforcement. Torture 16: 152-81.

9. REDRESS (2009) Rehabilitation as a form of Reparation under International Law 22.

10. UN Human Rights Committee: General Observation n ${ }^{\circ} 31$, Nature of the General Legal Obligation Imposed on States Parties to the Covenant, 26 May 2004 , $\$ 16$; George Kazantzis v. Cyprus, Comm. . n972/2001, Opinon of 7 August 2003, \$6.6, Bernadette Faure v. Australia, Comm. n¹036/2001, Opinion of 31 October 2005, \$7.2, and Final Observations on Egypt, Doc. ONU CCPR/C/79/Add.23, 9 August 1993, \$10.

11. Final Observations of the Committee against Torture: Tchad, CAT/C/TCD/CO/1, 4 June 2009, $\$ 17$.

12. Conclusions and Recommendations of the Committee against Torture: Turkey, 27 May 2003, CAT/C/CR/30/5 7, Para.h. As well as Conclusions and Recommendations of the Committee Against Torture: Benin CAT/C/XXVII/Concl.1, \$6.2.

13. CEDAW (1992) General Recommendation 19: Violence against Women, Turkey.

14. Çapan A (2014) Inter-American Human Rights System (Historical Progress and New Approaches to Contemporary problems (İnter-Amerikan İnsan Hakları sistemi (tarihsel gelişim ve güncel sorunlara yeni yaklaşımlar). Hukuk Kuramı 1: 25-44.

15. Inter-American Court of Human Rights Case of Tiu Tojín v. Guatemala, 2008.

16. Inter-American Court of Human Rights, Case of Valle Jaramillo et al. v. Colombia, 2008.

17. REDRESS (2009) Rehabilitation as a form of Reparation under International Law. 52.

18. Castillo Paez V, Peru (1998) 72 and Soler V.Colombia (2005) 101-3.

19. Blake V, Guatemala (1999) Inter-American Court of Human Rights.

20. Bulacio V, Argentine (2003) Inter-American Court of Human Rights.

21. Inter-American Court of Human Rights, Case of the 19 Merchants v. Colombia, 2004

22. Juvenile Re-education Institute v. Paraguay, 2004.

23. REDRESS (2009) Rehabilitation as a form of Reparation under International Law. 62.

24. Abdelgawad EL (2010) The European Court of Human Rights and the Reparation of Inhuman, Degrading and Torture Treatment: A Novice Jurisprudence? 238-9.

25. Bati and others v Turkey, 2004.

26. Shelton D (2007) The right to reparations for acts of torture: what right, what remedies?. Torture 17: 113.

27. Chamber V, Russia, 2008.

28. Türkmen V, Turkey, 2006. 


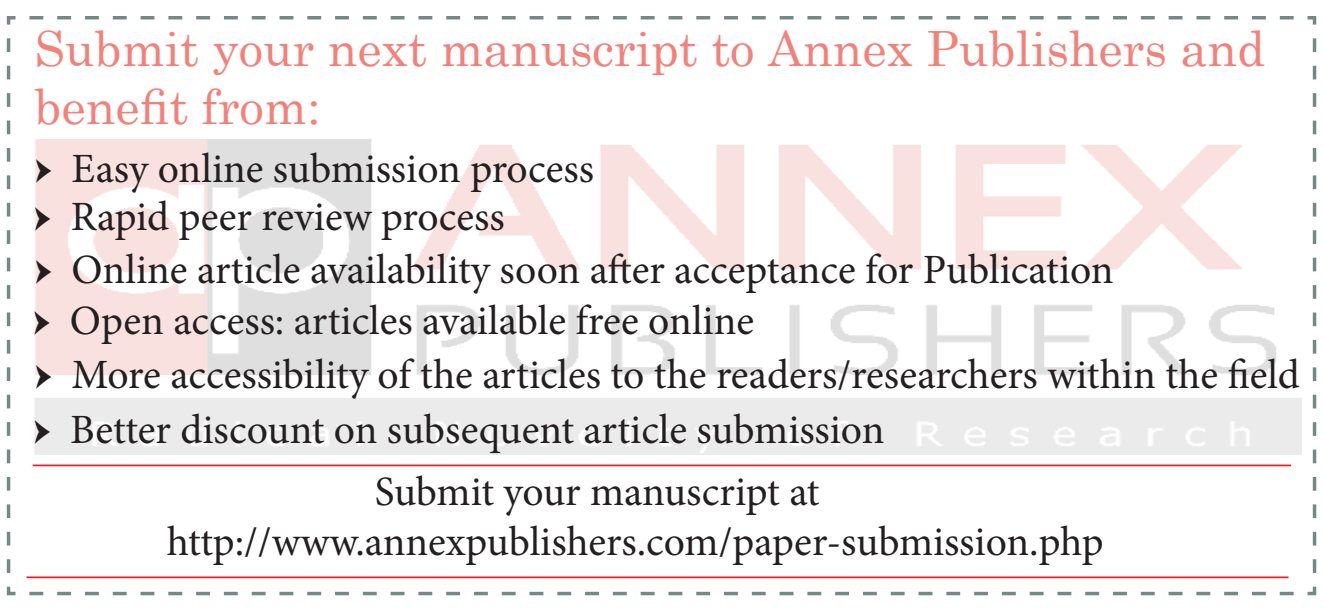

